\title{
Gross direct and embodied carbon sinks for urban inventories
}

Article

Accepted Version

Mohareb, E. and Kennedy, C. (2012) Gross direct and embodied carbon sinks for urban inventories. Journal of Industrial Ecology, 16 (3). pp. 302-316. ISSN 1088-1980 doi: https://doi.org/10.1111/j.1530-9290.2011.00445.x Available at https://centaur.reading.ac.uk/44985/

It is advisable to refer to the publisher's version if you intend to cite from the work. See Guidance on citing.

Published version at: http://dx.doi.org/10.1111/j.1530-9290.2011.00445.x

To link to this article DOI: http://dx.doi.org/10.1111/j.1530-9290.2011.00445.x

Publisher: Wiley

All outputs in CentAUR are protected by Intellectual Property Rights law, including copyright law. Copyright and IPR is retained by the creators or other copyright holders. Terms and conditions for use of this material are defined in the End User Agreement.

\section{www.reading.ac.uk/centaur}

\section{CentAUR}

Central Archive at the University of Reading

Reading's research outputs online 


\title{
Gross Direct and Embodied Carbon Sinks for Urban Inventories
}

\author{
Eugene A. Mohareb and Christopher A. Kennedy
}

\begin{abstract}
Cities and urban regions are under taking efforts to quantify greenhouse (GHG) emissions from their jurisdictional boundaries. Although inventorying methodologies are beginning to standardize for GHG sources, carbon sequestration is generally not quantified. This article describes t he methodology and quantification of gross urban carbon sinks.
\end{abstract}

Sinks are categorized into direct and embodied sinks. Direct sinks generally incorporate natural process, such as humification in soils and photosynthetic biomass growth (in urban trees, perennial crops, and regional forests). Embodied sinks include activities associated with consumptive behavior t hat result in the import and/or storage of carbon, such as landfilling of waste, concrete construction, and utilization of durable wood products.

Using methodologies based on the Intergovernmental Panel on Climate Change 2006 guidelines (for direct sinks) and peer-reviewed literature (for embodied sinks), carbon sequestration for 2005 is calculated for the Greater Toronto Area. Direct sinks are found to be 317 kilotons of carbon ( $\mathrm{kt} \mathrm{C}$ ), and are dominated by regional forest biomass. Embodied sinks are calculated to be $234 \mathrm{kt} \mathrm{C}$ based on one year's consumption, though a complete life cycle accounting of e missions would likely transform $t$ his sum from a carbon sink to a source. There is consider able uncertainty associated with the methodologies used, which could be addressed with city-specific stock-change measurements. Further options for enhancing carbon sink capacity within urban environments are explored, such as urban biomass growth and carbon capture and storage .

\section{Acknowledgements}

This study received financial support from people of Canada, through the Natural Sciences and Engineering Research Council. The authors would like to thank the anonymous reviewers of this article, and Professors Kim Pressnail, Heather MacLean, and Danny Harvey for their comments. As well, we greatly appreciate the assistance of Rike Burkhardt (City o f Toronto), Dan Clayton (Toronto and Region Conservation Authority [TRCA]), Meaghan Eastwood (TRCA), Andy Kenney (University of Toronto), John McNeil (City of Oakville), and Andrew Pickett (City of Toronto). 


\section{Introduction}

As the acceptance and understanding of climate change science has spread globally, it has been recognized that the majority of current greenhouse gas $(\mathrm{GHG})$ emissions can be attributed to urban dwellers. This is principally because more than $50 \%$ of the global population now lives in cities, with more than $75 \%$ of populations in more developed regions being urban by 2010 (UN, 2008). In their efforts to act on climate change, cities have taken up the task of emissions quantification to set emissions targets and identify reduction opportunities.

Quantifying emission sources allows a municipality to identify its major emitting sectors and set policies, fund projects and provide incentives for GHG reduction. However, the focus is placed on the sources of GHGs; potential carbon sinks are not typically assessed. Kennedy et al (2009) examined GHG emissions from 40 global cities and found that agriculture, forestry and land use (or AFOLU) are generally neglected, with only a few exceptions such as the cities of Calgary, Sao Paulo and Rio De Janeiro. Nowak and Crane (2002), Kenney et al (2001) and Pouyat (2002) have attempted to quantify carbon storage and/or carbon stocks in municipalities for forestry (former two) and soils (latter). As well, Pataki et al (2006) have provided estimates on several carbon sinks within the urban setting, though through a broad review of literature and not an inventorying approach for a specific city.

The Intergovernmental Panel Climate Change (IPCC) suggests that the $3.1{\mathrm{GtC} \mathrm{yr}^{-1}}^{-1}$ captured by the biosphere through terrestrial and ocean sinks annually (averaged between 2000-2005) is far from being balanced with the 7.2 $\mathrm{GtC} \mathrm{yr}^{-1}$ emitted from fossil sources and cement production (IPCC, 2007). They suggest that sink management activities

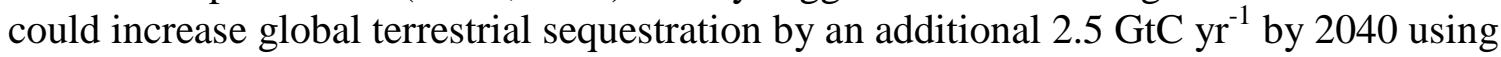
a range of options seen in Table 1 (IPCC, 2000). Even though many of these practices are rurally-based, they can be motivated through urban consumption.

Table 1: Carbon Sink Enhancement Activities Recognized under Article 3.4 of the Kyoto Protocol (from IPCC, 2000)

\begin{tabular}{|c|c|}
\hline \multicolumn{2}{|c|}{ Improved Management Practices } \\
\hline Cropland & $\begin{array}{l}\text { Reduced tillage, use of rotations/cover crops, fertility management, } \\
\text { erosion control, and irrigation management }\end{array}$ \\
\hline Rice Paddies & $\begin{array}{l}\text { Management of irrigation, chemical/organic fertilizers, and plant } \\
\text { residues }\end{array}$ \\
\hline Agroforestry & Better management of trees on croplands \\
\hline Grazing Land & Management of herds, woody plants and fires \\
\hline Forest Land & $\begin{array}{l}\text { Forest regeneration, fertilization, species selection for increased carbon } \\
\text { sequestration, reduced forest degradation }\end{array}$ \\
\hline Urban Land & Tree planting, management of waste and wood products \\
\hline \multicolumn{2}{|l|}{ Land Use Change } \\
\hline Agroforestry & Conversion of unproductive cropland and grasslands \\
\hline Restoration of & Conversion to cropland, grassland and forestland for lands not \\
\hline Degraded Lands & previously classified under these categories. \\
\hline Grassland & Conversion of cropland to grassland \\
\hline Wetland Restoration & Reverting drained areas back to wetland \\
\hline \multicolumn{2}{|c|}{ Off-Site Carbon Storage } \\
\hline Forest Products & Harvest and usage in long-lived applications \\
\hline
\end{tabular}


It is of interest to explore how the strategies described above relate to the urban environment. However, it is necessary to divide sinks into two broad groups; direct and embodied. A direct sink is one which ultimately results from carbon sequestered through biomass production within jurisdictional boundaries. An embodied sink is one that results from the consumption of a good or service where embodied carbon is involved.

This article has three related objectives. First, this article describes the concepts of direct and embodied carbon sinks within the urban context, and distinguishes between the two. Secondly, methodology for quantifying components of these two categories of sinks for cities are described based on peer-reviewed literature and IPCC guidelines, with the Greater Toronto Area (GTA) in the year 2005 used as a case study. The methodology allows cities to quantify annual increases in carbon stocks, which is beneficial in that it allows the establishment of baselines for future reference and comparisons between cities on sink stewardship (especially relevant to direct sinks). This is followed by the third objective, which is to discuss the potential for carbon sink enhancement.

Methodologies used in the direct sinks quantified in this article are based on the IPCC 2006 guidelines to provide a means of quantifying both GHG sources and sinks. As with all IPCC (2006) methodologies for carbon inventory, carbon stock growth is quantified using one of three tier levels, with Tier 1 methodologies being the most basic and Tier 3 the most complex. IPCC Tiers 1 and 2 are generally used in this study.

One may argue that sinks within the urban boundary are insignificant compared to urban emissions (e.g. 15.8 MtC emitted from the GTA in 2005; Kennedy et al, 2010) and are relatively small when compared to national-scale carbon sinks. However, there are three reasons why quantification is of value: 1) If the objective is for cities to ultimately move towards a closed-loop carbon system, sinks accounting is inevitable; 2) Sinks often have many indirect benefits such as increased shading, evapotranspirative cooling for urban trees (Akbari, 2002) and improved soil fertility and greater yields for soil sequestration (Robert, 2001); 3) Urban-scale quantification has the potential to provide greater resolution for modelling efforts on the national scale if a sophisticated methodology is employed, reducing uncertainty.

\section{Background - Direct and Embodied Sinks}

It is important to define and distinguish between direct and embodied sinks prior to examining illustrations. Direct sinks are those which result from carbon storage through management activities for relevant biological resources within the inventory's spatial boundary. Embodied sinks differ from these in that their existence within the spatial boundary is attributable to the utilization of a sequestering resource (one that has sequestered carbon or has the potential to do so), independent of its origin. The embodied sink exists due to consumer demand within the urban boundary.

The differences between direct and embodied sinks are illustrated by examples in Figure 1. Carbon uptake via photosynthesis results in direct biomass growth that yields an increasing carbon stock over time (Figure 1a). The quantity of the direct carbon sequestered is represented by the negative change in carbon emissions year over year. The Figure depicts a disturbance occurring at year 100, such as a forest infestation (the 
rate and extent of carbon release will vary based on pathway). This results in a carbon release, though otherwise, it is presumed the accumulation of carbon will continue.

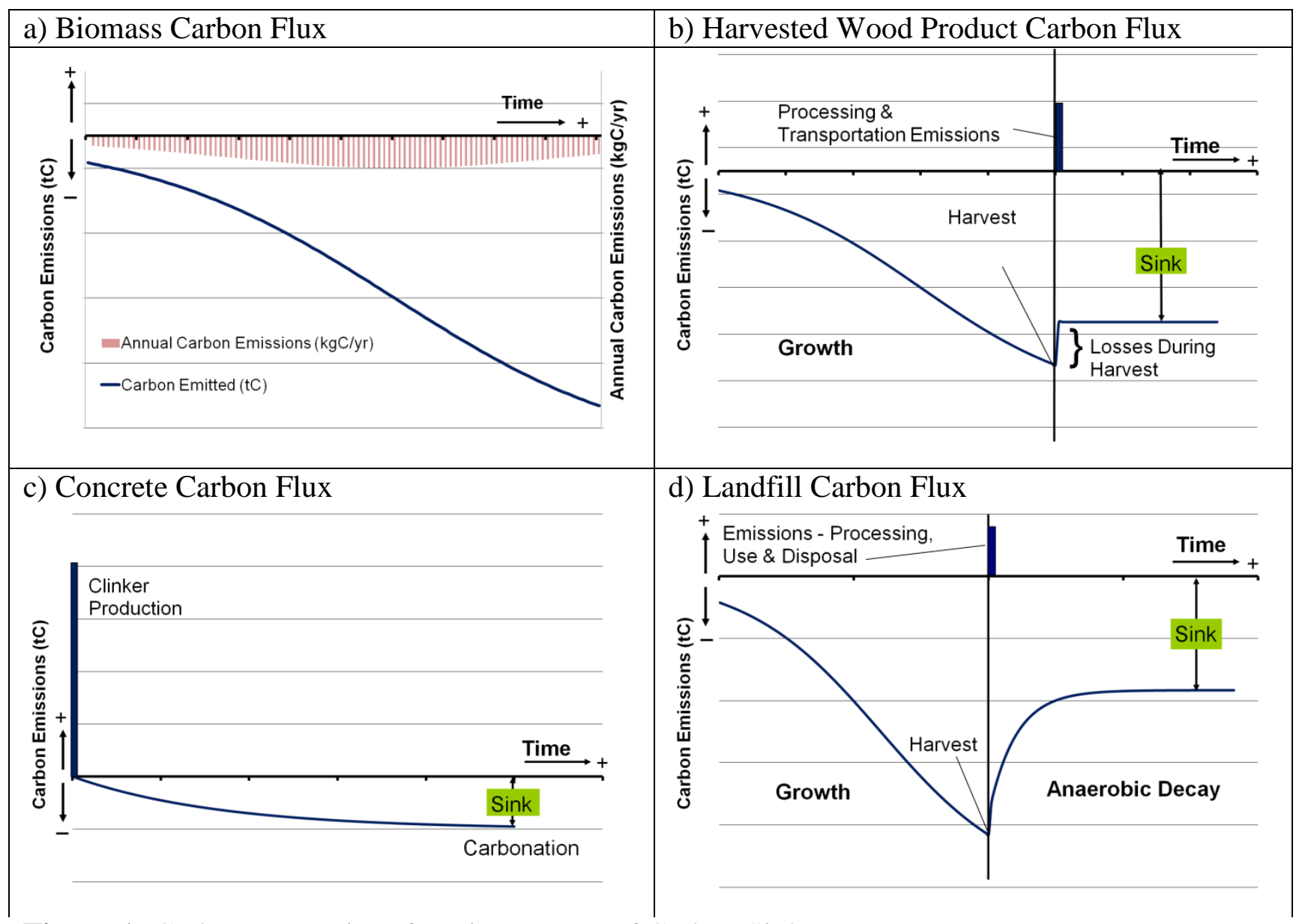

Figure 1: Carbon Dynamics of Various Types of Carbon Sinks

Direct carbon sinks, measured annually, can be compared to the embodied carbon sinks, which are estimated by their potential for long-term carbon stock creation. The embodied sinks considered here are concrete, Harvested wood products (HWPs) and landfilled waste (containing biogenic carbon). HWPs represent an embodied sink as they contain the biogenic carbon from forestry products as long as they are prevented from decaying (Figure 1b). Concrete naturally undergoes long-term carbonation after setting, a degradative process which results in carbon storage (fulfilling its embodied potential to sequester carbon; Figure 1c). Lastly, due to prevention of complete decomposition of embodied biogenic carbon under anaerobic conditions, carbon stocks increase as long as organic wastes are deposited in sanitary landfills (Figure 1d).

The direct sink concept (shown in Figure 1a for forestry biomass) is relatively straightforward, as sequestration from biomass occurs in forests and soils within the urban boundary; as long as biomass stocks remain in the growth phase, the direct carbon sink (e.g. forest stands) expands. The incremental annual growth would represent the inventoried stock gain. Similarly, if soils have not reached their capacity for carbon storage (related to soil type, climate, land-use, and management practices), growth in carbon stocks will occur. 
Embodied sinks have more complexity associated with their spatial boundaries. Where direct sinks occur strictly within urban boundaries, the creation of the carbon stock (or the potential for a stock) for embodied sinks can occur at either side of the jurisdictional boundary. More precisely, industries that manufacture these means of carbon sequestration may or may not be within the urban boundary, but the consumer demand which drives their production, consumption and resultant disposal must be. Embodied sinks that are exported to other jurisdictions would not be included. Emissions associated with use, installation, processing, harvesting or disposal are not counted against the gross sinks total (refer to Figures $1 \mathrm{~b}, \mathrm{c}$ and d). If a comprehensive consumer-side emissions inventory is conducted, emissions associated with the production and/or use of these products will be captured and can then be contrasted against carbon stock growth. However, the focus of this article is solely on gross and not net sinks; upstream quantification is examined in supplementary material (see heading "Unquantified Sources and Sinks"). Efforts in taking a consumers approach in emissions inventorying show that greater accountability by the end-use can be achieved when a broader view of emissions associated with consumption is taken. As suggested in Figure 1, when relevant emissions are not considered, the perception of a larger carbon sink is created. Both direct and embodied sinks neglect emissions; however, we suggest that, using a lifecycle perspective, embodied sinks are likely to be a net emissions source.

Concrete and HWPs are the most consumed construction materials by weight according Brunner and Rechberger (2002), leading them to be two of the most important material stocks. Additionally, landfills are a common disposal destination for biogenic carbon materials. This is not meant to be a comprehensive inventory of embodied sinks; books and products containing natural rubber are a few other examples of biogenic carbon stocks in the urban environment. Instead, the aim here is to illustrate the quantification of some key embodied sinks.

Embodied sinks described here are allocated to the city that consumes/handles the associated means of storage. For example, HWPs (Figure 1b) may or may not be extracted from within an urban boundary; however our interest is in the principal motivation behind the creation of the sink (the consumer) and the sink is allocated accordingly. Pre-harvest, the biomass provides a direct carbon sink within the jurisdiction that it exists.

Miner and Perez-Garcia (2007) estimate global $\mathrm{CO}_{2}$ storage in HWPs for 2005 was 200 $\mathrm{Mt} \mathrm{CO}_{2} \mathrm{e} \mathrm{yr}^{-1}$, roughly $0.5 \%$ of global net primary production. As one would presume, carbon in the form of biomass harvested for use in forestry products does not immediately return to the atmosphere from which it was drawn (the assumption under initial IPCC inventory methodology in 1996). Hashimoto et al. (2002) show that a signification carbon storage potential exists, amounting to a carbon sink that was $2 \%$ of the 1990 emissions baseline for a group of Annex I countries. Post-harvest, any carbon remaining in the HWP consumed by a city represent an increase in the embodied carbon stock within the urban boundary.

Cement represents a significant industrial sector emitter of GHGs. Through the calcination of limestone and combustion of fossil fuels, cement production contributes roughly $5 \%$ to global (and 4\% of GTA) $\mathrm{CO}_{2}$ emissions (Pade and Guimaraes, 2007; Kennedy et al, 2010). When combined with aggregates, additives and water in an urban 
environment, concrete, the ubiquitous urban material stock, is formed (predominantly calcium hydroxide, $\mathrm{Ca}(\mathrm{OH})_{2}$; Haselbach and $\left.\mathrm{Ma} 2008\right)$. Over time, carbon dioxide diffuses into concrete, creating the more stable compound calcium carbonate $\left(\mathrm{CaCO}_{3}\right)$, a process described by the reaction:

$$
\mathrm{Ca}(\mathrm{OH})_{2}+\mathrm{CO}_{2} \rightarrow \mathrm{CaCO}_{3}+\mathrm{H}_{2} \mathrm{O}
$$

The degree of carbonization is dependant primarily on concrete thickness (i.e. exposed surface area) and clinker concentration; the greater the clinker concentration and surfaceto-volume ratio, the greater the degree of carbonization (Galan et al. 2010).

Pade and Guimaraes (2007) suggest that carbon uptake from concrete stocks for a single year may be between 14-25 kgC sequestered per cubic meter over a 100-year timeframe (Table 2). All carbon anticipated to be absorbed by concrete used in construction in a given year represents an increase in the urban carbon stock.

Table 2: Summary of Concrete Production and Uptake for Concrete Poured in 2003 (Adapted from Pade and Guimaraes, 2007)

\begin{tabular}{lllll}
\hline Country & Norway & Denmark & Sweden & Iceland \\
\hline Concrete Produced, $\mathrm{Mm}^{3}$ & 3.3 & 3.9 & 4.0 & 0.4 \\
$\begin{array}{l}\text { C Uptake, tons C m } \\
\text { (100 year timeline) }\end{array}$ & 60,000 & 93,000 & 65,000 & 8,000 \\
$\begin{array}{l}\text { C uptake, } \mathrm{kgC} \mathrm{m}^{-3} \\
(100 \text { year timeline) }\end{array}$ & 18 & 23 & 16 & 14 \\
\hline
\end{tabular}

Finally, disposal of biogenic materials in landfill sites represents a waste management practice that results in long-term storage of biogenic carbon (Figure 1d). The US annual national inventory report includes a section detailing the contribution of food scraps and yard trimmings to this type of sink (USEPA, 2009); these biogenic carbon stocks would likely degrade aerobically under natural conditions, resulting in the release of embodied carbon. Though the landfill site may not be operated by the municipality or be located within the urban boundary, waste deposited is a result of a city's consumptive activities. As well, selection of the waste treatment option lies within municipal jurisdiction and as a result of these considerations, the increased carbon stock is credited to the consumers who use the materials.

IPCC methodologies for waste management are primarily concerned with year-over-year emissions due to methane release. This approach is rational when addressing the immediate concern of GHG emission reduction, but work by Barlaz (1998) demonstrates that decomposition within landfills is generally incomplete under anaerobic conditions. Moreover, work by the USEPA (2006) applying Barlaz's work suggests that organics deposited in landfills will result in a net carbon sink over the life-cycle, even after considering methane emissions (assuming 75\% LFG collection and 10\% oxidation). From a consumer standpoint, when neglecting all emissions associated with production, distribution and usage of materials deposited in landfills, municipal solid waste (MSW) represents a carbon sink.

It should be noted that temporal boundaries differ for embodied and direct sinks; embodied sinks assume an extended timescale starting from when materials are consumed by the inventoried jurisdiction, whereas direct sinks use a timescale of a single 
year of carbon removal. Considering lumber as an example, a tree during the course of growth is classified as a direct sink, with the carbon stock growth within the biomass contributing to the direct sink inventory of the jurisdiction in which it is growing. However, once the tree is harvested, it ceases to contribute to the direct sink for that jurisdiction, as it no longer is sequestering carbon. If the tree is processed into lumber, it then becomes a stock of carbon, providing an embodied sink within the jurisdiction it is consumed. Similar decisions on temporal boundary selection are made in emissions inventorying landfill gas; the Theoretical Yield Gas approach applies a boundary similar to the embodied sink (projecting forward), however the waste-in-place calculation is similar to the direct sink temporal boundary (year of inventory; see Mohareb et al, 2011 for more details). A stock-change method could be applied, though historic data would be required to determine stock magnitude and age, which would be difficult to obtain or estimate accurately. For example, if one were to inventory current carbon stocks in harvested wood products, an accounting of all buildings, their era / method of construction and any renovations occurring would need to be known. Additionally, direct sinks quantified here generally use the IPCC (2006) guidelines for quantification whereas embodied sink quantification methods are adapted from literature.

One final point on the bounding of the study is on the choice of using regional vs city bounds. When selecting boundaries of GHG sinks, it seems appropriate to use as broad a spatial urban boundary as possible. GHG emissions are ultimately a sustainability issue and their reduction will require the application of closed-loop analysis. As suggested by Rees (1997), the sustainable city will likely be a more self-reliant one; when attempting to classify a city as sustainable, the systems which support it must come into consideration. Using the broader urban geographical boundary (such as a regional one rather than municipal) facilitates this quest somewhat, providing a greater resource base to draw from in the transition to a balanced urban carbon budget. 


\section{Methodology}

Using IPCC (2006) methodologies, approaches for quantifying direct carbon sinks are presented below. This is followed by the quantification of embodied carbon sinks, the calculation of which is based on various data and literature sources.

\section{Direct Sinks}

Under national inventories, all lands designated as "managed lands" are applicable for GHG source/sink quantification. The IPCC (2006) defines these as "lands where human interventions and practices have been applied to perform production, ecological or social functions". Typically, lands within urban boundaries would hence be considered managed lands.

Under IPCC (2006) inventory protocol, trees/forests contribute to five carbon pools:

1) Above Ground Biomass

2) Below Ground Biomass

3) Dead Wood - Non-living, standing woody biomass or fallen biomass that is generally greater than $10 \mathrm{~cm}$ in diameter

4) Litter - Non-living biomass $(2 \mathrm{~mm}<$ diameter $<10 \mathrm{~cm})$

5) Soil Carbon

Above and below ground biomass increase carbon storage through photosynthetic processes (Net Primary Production, NPP), whereas dead wood and litter, classified as dead organic matter (DOM), generally act as carbon sources. DOM can accumulate above ground (due to their slow degradation) and add to the soil carbon stock during decay.

As these are gross carbon storage inventories, DOM and litter contributions to emissions are not estimated. The first two biomass pools listed will be described in below, detailing calculations of the annual soil carbon flux.

\section{Forests}

Forests provide a carbon storage opportunity by means of sequestration in live biomass, soil organic carbon, litter and dead organic matter. Even old growth forests have the capability to increase carbon stocks in the long term (though this does appear to diminish over time), with century old forests storing more carbon per annum than is released through respiration (Luyssaert et al. 2008).

\section{$\underline{\text { Urban Forests }}$}

Work on carbon sequestration estimation for urban areas has been previously undertaken, such as by McPherson (1998) and Novak and Crane (2002; using the Urban Forest Effects Model or UFORE). The crown cover area-based inventorying method used in this study (and by the IPCC, 2006) is based on the work of Nowak and Crane (2002). 
Wright (2000) provides land use data based on GIS information sourced from regional conservation authorities which allows for Tier 2 quantification of Urban Forests in the GTA. The total settlement area is given as $2361 \mathrm{~km}^{2}$. Urban canopy data were obtained from the City of Toronto's Urban Forestry Department (Pickett, personal communication, March 19, 2008), and the figure of $17.5 \%$ crown coverage is applied to all settlement areas across the GTA (giving a total canopy area of $401 \mathrm{~km}^{2}$. Canopy data are not available for all municipalities in the GTA, however an urban forestry professional at the Toronto Region Conservation Authority suggests that this is a reasonable assumption (Eastwood, personal communication, April 8, 2010). As stated earlier, the target year for carbon sink calculations was the year 2005. However, the most recent GIS data available are for 2000, and Toronto's urban canopy data are from the year 2000. It is assumed that the change in urban canopy and settlement area between 2000 and 2005 is negligible.

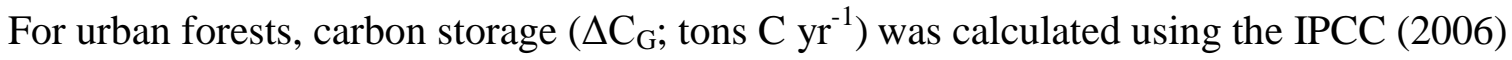
Tier 2a methodology:

$$
\Delta \mathrm{C}_{\mathrm{G}}=\Sigma \mathrm{A}_{\mathrm{i}, \mathrm{j}} \cdot \mathrm{CRW}_{\mathrm{i}, \mathrm{j}}
$$

where

$\mathrm{A}_{\mathrm{i}, \mathrm{j}}=$ Total Crown Cover Area of Class i Woody Perennial type $\mathrm{j}$ (ha)

$\mathrm{CRW}_{\mathrm{i}, \mathrm{j}}=$ Crown Cover Area-based Growth Rate of Class i in Woody Perennial Type $\mathrm{j}$, tC (ha crown cover) ${ }^{-1} \mathrm{yr}^{-1}$; default value of 2.9 is applied in this study

\section{$\underline{\text { Regional Forest Biomass }}$}

The IPCC (2006) calculation of regional forests carbon sequestration is more complex than for urban forests, as their magnitude on the national level far exceeds that of forests within settlements. Data for IPCC (2006) Tier 1 (Gain-Loss method) quantification of regional forests is given through GIS data provided by Wright (2000), with default values for IPCC (2006) methodology used for emission factors (Table 3).

Table 3: Emission Factor and Parameters Used in Regional Forestry Calculations

\begin{tabular}{cccc}
$\begin{array}{c}\text { Average Annual Above } \\
\text { Ground Biomass Growth } \\
\left(\mathrm{G}_{\mathrm{w}}\right)(\mathrm{t} / \mathrm{ha}-\mathrm{yr})\end{array}$ & $\begin{array}{c}\text { Above-Ground : Below- } \\
\text { Ground Biomass (R) } \\
\text { Conifer / Broad Leaf }\end{array}$ & $\begin{array}{c}\text { Carbon Fraction of Dry } \\
\text { Matter (CF) } \\
\text { Conifer / Broad Leaf }\end{array}$ & $\begin{array}{c}\text { Land Area (A) } \\
\text { Conifer/Broad Leaf } \\
\left(\mathrm{km}^{2}\right)\end{array}$ \\
\hline $4(0.5-7.5)^{1}$ & $0.29 / 0.23^{1}$ & $0.51 / 0.48^{1}$ & $215 / 430^{2}$ \\
\hline $1-$ Default IPCC Value (Tables, $4.4 .9,4.4$ and $4.4 .3-$ North American, Temperate) $2-$ From Wright
\end{tabular}

1 - Default IPCC Value (Tables, 4.4.9, 4.4.4 and 4.4.3 - North American, Temperate), 2 - From Wright (2000)

An above-ground biomass density of $130 \mathrm{tha}^{-1}$ estimate is used based on IPCC (2006) estimates for North American temperate forests greater than 20 years of age. Calculation of annual regional forest carbon storage are made using Equations 3 and 4 .

$$
\Delta C_{G}=\sum\left(A \bullet G_{T O T A L} \bullet C F\right)
$$

$\mathrm{CF}=$ Carbon Fraction of dry matter (d.m.)

$\mathrm{G}_{\text {total }}=$ Mean annual above and below ground biomass growth ( $\mathrm{t}$ d.m. $\mathrm{ha}^{-1} \mathrm{yr}^{-1}$ )

$\mathrm{A}=$ Land Area (ha) 


$$
G_{T O T A L}=\sum\left\{G_{W} \bullet(1+R)\right\}
$$

$\mathrm{G}_{\mathrm{w}}=$ average annual above ground biomass growth (t d.m./ ha-yr) $\left(\mathrm{G}_{\mathrm{w}}=4.0\right)$

$\mathrm{R}=$ Ratio of below ground : above ground biomass for specific type

\section{Perennial Crops}

Another woody biomass carbon sink can be found in agricultural land use. With over 5000 ha of perennial crops in the GTA in 2005, it is reasonable to quantify the related carbon storage (modified from Statistics Canada, 2002; 2007).

A Tier 1 approach is demonstrated using default IPCC (2006) data for a temperate climate. It is assumed that all perennial crops have not reached maturity (i.e. carbon is accumulating in biomass) and that tree removal is not taking place. In the case of Christmas trees, it is assumed that $10 \%$ are harvested annually, leaving only $90 \%$ to contribute to annual carbon stock (Christmas Tree Farmers of Ontario, 2010). Carbon sequestration from perennial crops is determined by

$$
\Delta C_{G}=\sum_{i}\left(A_{i} \bullet G\right)
$$

where $\mathrm{A}_{i}=$ Total area of cropland type $i$ (ha)

$\mathrm{G}=$ Biomass accumulation rate (tons $\mathrm{C} \mathrm{ha}^{-1} \mathrm{yr}^{-1}$ ); 2.1 given as temperate region default (IPCC 2006, Table 4.5.1)

As with other methodologies in this article, gross quantification of carbon storage is performed and emissions from agricultural operations are not calculated. Data from 2005 is interpolated linearly for GTA perennial crops (fruits, berries, nuts, nursery crops and Christmas trees) using 2001 and 2006 census data, and are provided in Table 4. This table also provides agricultural data that is applied in the soil carbon quantification methodology (seeding practices and manure application).

\begin{tabular}{|c|c|c|c|c|c|c|}
\hline & Year & Halton & Peel & York & Durham & Toronto \\
\hline \multicolumn{7}{|c|}{ Perennial Crops (ha) } \\
\hline \multirow[t]{2}{*}{ Christmas Trees } & 2006 & 82 & 55 & 291 & 303 & 0 \\
\hline & 2001 & 74 & 104 & 362 & 420 & 0 \\
\hline \multirow[t]{2}{*}{ Nursery } & 2006 & 1,023 & 173 & 363 & 967 & 0 \\
\hline & 2001 & 1,034 & 277 & 279 & 927 & 0 \\
\hline \multirow[t]{2}{*}{ Fruit Crops } & 2006 & 348 & 226 & 486 & 683 & 0 \\
\hline & 2001 & 323 & 211 & 264 & 851 & 0 \\
\hline \multicolumn{7}{|c|}{ Seeding Practices (ha) } \\
\hline \multirow[t]{2}{*}{ Full Tillage (ha) } & 2001 & 7,845 & 10,222 & 21,463 & 30,892 & 0 \\
\hline & 2006 & 5,496 & 10,151 & 14,515 & 24,803 & 0 \\
\hline \multirow[t]{2}{*}{ Low-Till (ha) } & 2001 & 6061 & 8,144 & 7,945 & 17,518 & 0 \\
\hline & 2006 & 5,925 & 6,349 & 10,677 & 21,227 & 0 \\
\hline \multirow[t]{2}{*}{ No-Till (ha) } & 2001 & 8,997 & 4,067 & 8,961 & 13,087 & 0 \\
\hline & 2006 & 8,814 & 4,710 & 8,818 & 19,200 & 0 \\
\hline \multicolumn{7}{|c|}{ Farms Applying Manure (units) } \\
\hline \multirow{2}{*}{$\begin{array}{l}\text { Farms Applying } \\
\text { Total Farms }\end{array}$} & 2006 & 233 & 242 & 360 & 943 & 0 \\
\hline & & 566 & 483 & 972 & 1686 & 0 \\
\hline
\end{tabular}

Table 4: Agricultural Data in GTA (Statistics Canada, 2002; 2007) 


\begin{tabular}{|c|c|c|c|c|c|c|}
\hline $\begin{array}{r}\text { Farms Applying } \\
\text { Tota }\end{array}$ & 2001 & $\begin{array}{l}248 \\
550\end{array}$ & $\begin{array}{l}301 \\
481\end{array}$ & $\begin{array}{l}411 \\
931\end{array}$ & $\begin{array}{l}1262 \\
1540\end{array}$ & 0 \\
\hline
\end{tabular}

\section{Soils}

Soils represent an enormous potential organic carbon sink. Post and Kwon (2000) suggest that in many terrestrial ecosystems, more carbon is stored in soils than the biomass it supports. Soil carbon fluxes are generally a function of climate, which affects net primary production and their resultant inputs through DOM (Kirschbaum 2000). Current land use and management practices have lead to the degradation of soils and the release of carbon through decomposition and mineralization. However, improved management practices can lead to increased carbon stocks in soils through the assimilation of carbon from biomass sources such as tree litter, crop residues, and root systems.

Soils are classified into two broad categories under IPCC (2006) methodology: mineral and organic soils. Mineral soils are those that are moderately-to-well drained and represent the most significant soil type for the manipulation of carbon fluxes through land management practices. Organic soils are found in poorly drained locations (such as wetlands) and are able to store much greater quantities of carbon due to the anaerobic environment provided.

In 2000, GTA land area was found to contain roughly $86 \mathrm{~km}^{2}$ of wetlands (or roughly $1 \%$ of the total area; Wright, 2000). As this is relatively low and little sequestration is expected (IPCC Tier 1 methodology is primarily concerned with carbon releases due to drainage), organic soils will be neglected from this sink calculation.

The IPCC (2006) general equation for calculating the annual soil carbon flux is:

$$
\Delta C_{\text {Soils }}=\Delta C_{\text {Mineral }}-L_{\text {Organic }}+\Delta C_{\text {Inorganic }}
$$

where:

$\Delta \mathrm{C}_{\text {Soils }}=$ annual change in soil carbon stock, tons ${\mathrm{C} \mathrm{yr}^{-1}}^{-1}$

$\Delta \mathrm{C}_{\text {Mineral }}=$ annual change in organic carbon in mineral soils, tons ${\mathrm{C} \mathrm{yr}^{-1}}^{-1}$

$\mathrm{L}_{\text {Organic }}=$ annual loss of carbon due to organic soil drainage, tons ${\mathrm{C} \mathrm{yr}^{-1}}^{-1}$

$\Delta \mathrm{C}_{\text {Inorganic }}=$ annual change in inorganic carbon from soils, tons ${\mathrm{C} \mathrm{yr}^{-1}}^{-1}$

IPCC (2006) states calculations for inorganic carbon changes are site dependent and require examination of soil mineralogy and are ignored here (which is assumed reasonable considering Canadian national inventories exclude this category). A tier 1 approach for forest soils assumes no change in carbon stocks year over year (higher tiers would also require site-specific measurements; see Supplementary Material under "Soils" for estimates in the GTA). Robert (2001) suggests that in natural forests, soils are in equilibrium until deforestation occurs. 
Pouyat et al (2002) have studied soil organic carbon pools in three urban areas (New York City, Chicago, and Moscow). Through direct soil measurements, a wide variety of soil carbon density $\left(\mathrm{kg} \mathrm{m}^{-2}\right)$ was observed in urban ecosystems. Carbon densities in residential zones were on par with those observed in forested zone in the same climatic region, though undeveloped areas within urban centres could also be lower than forested areas. In a more recent study, Pouyat et al (2009) demonstrated that urban turfgrass and remnant forests in Denver, CO and Baltimore, MD, respectively, contained greater carbon stocks than natural shortgrass prairie and rural forests, which may be attributable to higher inputs in the former.

These studies evidence a great deal of complexity and uncertainty in quantifying carbon fluxes for soils in urban area, due to variation in inputs, management practices, land cover and micro climate. Impervious cover (roads, buildings, parking lots etc) are not undergoing measurable changes in soil carbon as the inputs of litter and root systems are not available, which leaves turfgrass and urban forest (Pouyat et al, 2006). Additionally, they generally examine stocks and compare these with undeveloped areas; it would be valuable to examine stock changes within a specific land use type. It is evident that further study is required before generalized methodologies are available on quantification of urban soils. For similar reasons, the IPCC 2006 methodology neglects carbon flux within settlements without direct measurement.

\section{$\underline{\text { Agriculture }}$}

The IPCC 2006 guidelines use a stock change methodology to describe changes in mineral soil carbon storage. For a given climate zone, soil type and management system, soil organic carbon (SOC) stock in mineral soils are calculated using Equations 7 and 8.

$$
\begin{gathered}
\Delta C_{\text {Mineral }}=\frac{\left(S O C_{0}-S O C_{(0-T)}\right)}{D} \\
\mathrm{SOC}=\mathrm{SOC}_{\mathrm{REF}} \bullet \mathrm{F}_{\mathrm{LU}} \bullet \mathrm{F}_{\mathrm{MG}} \bullet \mathrm{F}_{\mathrm{I}} \bullet \mathrm{A}
\end{gathered}
$$

where:

$\Delta \mathrm{C}_{\text {Mineral }}=$ change in soil organic carbon (SOC) stocks in mineral soils, tons ${\mathrm{C} \mathrm{yr}^{-1}}^{-1}$

$\mathrm{SOC}_{0}=\mathrm{SOC}$ in the last year of an inventory time period, $\mathrm{tC}$

$\mathrm{SOC}_{(0-\mathrm{T})}=\mathrm{SOC}$ at the beginning of an inventory time period, $\mathrm{tC}$

$\mathrm{T}=$ number of years over a single inventory time period, $\mathrm{yr}$

$\mathrm{D}=$ time dependence of stock change factors (default value of 20 is used)

$\mathrm{SOC}_{\mathrm{REF}}=$ Reference Carbon Stock, $\mathrm{tC}$

$\mathrm{F}_{\mathrm{LU}}=$ Stock change factor for land-use systems

$\mathrm{F}_{\mathrm{MG}}=$ Stock change factor for a management regime

$\mathrm{F}_{\mathrm{I}}=$ Stock change factor for input of organic matter

$\mathrm{A}=$ Land Area, ha

The GTA lies in a cool, temperate, moist climate zone as categorized by the IPCC (2006). Table 5 lists all stock change factors used, along with some assumptions (IPCC 2006, Tables 4.2.3, 4.5.5). Agricultural Census data is used to provide changes in farming 
practices for the GTA and is presented in Table 4. IPCC defaults are used for $\mathrm{F}_{\mathrm{UG}}, \mathrm{F}_{\mathrm{MG}}$, and $\mathrm{F}_{\mathrm{I}}$.

Using the soil association map of Southern Ontario (Agriculture and Agri-Food Canada, 1960) and land use maps from Wright (2000), it is observed that the region's agricultural land is dominated by clay (Peel, Halton) and loam (York, Durham). From

VandenBygaart et al (2004), it is shown that luvisol comprises the greatest proportion of Ontario soils; hence, it is assumed that all cropland soils are high activity clay.

Table 5: Stock Change Factors and Key Assumption used in Cropland Carbon Sink Calculations (IPCC, 2006)

\begin{tabular}{lll}
\hline Stock Change Factor & Quantity Used & Assumptions \\
\hline SOC $C_{\text {REF }}$ & 95 & Cropland is High Activity Clay \\
$\mathrm{F}_{\mathrm{LU}}$ & 0.69 & Long-term Cultivated \\
$\mathrm{F}_{\mathrm{LU}}$ & 1.00 & Perennial / Tree Crop \\
$\mathrm{F}_{\mathrm{MG}}$ & 1.00 & Full Tillage \\
$\mathrm{F}_{\mathrm{MG}}$ & 1.08 & Reduced Tillage \\
$\mathrm{F}_{\mathrm{MG}}$ & 1.15 & No Tillage \\
$\mathrm{F}_{\mathrm{I}}$ & 1.11 & High Input \\
$\mathrm{F}_{\mathrm{I}}$ & 1.44 & High Input with Manure \\
\hline
\end{tabular}

Agricultural land uses are assumed to be long-term cultivated. $F_{M G}$ and $F_{I}$ are weighted in proportion to reported farm practices. The proportion of farms using manure is assumed to be equivalent to fraction of total farm area using manure and hence is weighted as stated in Table 4 (48, 63\% in 2006 and 2001, respectively). High input agriculture (including irrigation, fertilization, etc) will generally lead to a faster rate of soil carbon accumulation, though certain practices (such as the application of lime and nitrogen fertilizer) can result in a net positive GHG flux (IPCC, 2006). As the number of farms applying manure decreased in the GTA between the two census years, a reduction in the annual carbon storage potential of agricultural soils occurred.

For the calculation of total carbon sequestered in the GTA, the total cropland area in 2006 was used. It should be noted that total cropland declined 3\% from 2001 to 2006;

however, the effect of this on the carbon sink calculation was negligible. A 2006 total agricultural census area of 140,700 ha is applied to Equation 7.

The implementation of conservation agriculture practices generally results in a relatively rapid short-term increase in carbon storage in cropland soils. However, it is important to note that conversion of agricultural land to perennial, unharvested vegetation will lead to greater carbon storage rates and total carbon stocks, as emphasized in Post and Kwon (2000).

\section{Embodied Sinks}

\section{Landfill Waste}

Using USEPA (2006) coefficients for non-degraded carbon under anaerobic conditions (provided in supplementary material, Table S.1) and waste audits for the City of Toronto, 
a spreadsheet calculation was made for the long-term carbon sequestration for waste deposited in 2005. This waste includes both residential (divided into single family housing (SFH) and multi-unit (MU) dwellings) and non-residential waste, with an assumption that composition did not vary across the GTA for the dwelling types.

Residential waste composition is tabulated using 2005-2006 waste audits for the City of Toronto for MU and SFH (Stewardship Ontario, 2006). Non-residential waste composition is tabulated using data from TCSA (2008) and City of Toronto (1991). Total waste deposited in landfills is taken from regional data for residential waste and TCSA (2008) for commercial waste, with 796,000, 361,000 and 3,000,000 tons of MSW from single family units, multi-unit residential and non-residential, respectively. Woody biomass is composted in the GTA, and is assumed to provide no net carbon storage.

The waste carbon sink provided by landfills is calculated using Equation 9.

$$
\text { Carbon Storage (tons } \left.\mathrm{C} \mathrm{yr}^{-1}\right)=\sum_{W F} C S F_{W F} \bullet T_{W F}
$$

where WF = waste fraction (by type, see Supplementary Material S.2), $\mathrm{CSF}_{\mathrm{WF}}=$ net carbon storage factor for a given waste fraction (tons $\mathrm{C}^{-1}$ ), and $\mathrm{T}_{\mathrm{WF}}=$ tonnage of a given waste fraction deposited in landfills (tons $\mathrm{yr}^{-1}$ ). It should be noted that the USEPA WARM model quantifies all biogenic carbon storage in landfills, not just yard waste and food scraps as is done in the US national inventory.

\section{Cement / Concrete}

When concrete is poured within the urban environment, this carbonation process represents an additional embodied carbon sink. Using the assumption of Sahely et al (2003) of 180 tons of concrete consumed on the municipal scale per housing unit construction started, and Statistics Canada (2010) data giving 42,000 housing starts in 2005, concrete consumption in the GTA is estimated to be 7,500,000 t. Pade and Guimaraes (2007) present estimations of life-cycle carbonation of concrete from four Scandinavian countries (Table 1), based on utilization and recycling practices of concrete. These are applied to GTA data to determine potential for carbonation of concrete consumed, using weighted averages from each country. Calculations of anticipated carbon sequestration over a 100 year timeline of concrete consumed in the inventory year are made assuming the following:

1) Similar distribution of cement uses in the GTA as the weighted Nordic average, giving a carbon uptake $1.93 \times 10^{-2}$ tons $\mathrm{m}^{-3}$ (see Table 2 )

2) Density of concrete of $24 \mathrm{kN} / \mathrm{m}^{3}\left(2.45\right.$ tons $\left./ \mathrm{m}^{3}\right)$

3) 70 year useful life and 30 year post-demolition (recycling)

$$
\text { Carbon storage }\left(\text { tons } \mathrm{yr}^{-1}\right)=\left(\mathrm{T} / \rho_{\mathrm{c}}\right) \cdot \mathrm{CU}
$$

where $\mathrm{T}=$ concrete consumption (tons $\left.\mathrm{yr}^{-1}\right), \rho_{\mathrm{c}}=$ concrete density (tons $\left.\mathrm{m}^{-3}\right), \mathrm{CU}=$ carbon uptake (tons $/ \mathrm{m}^{3}$ ). 


\section{Harvested Wood Products}

The useful life of HWPs varies depending on application and this must be considered. For example, fuelwood or consumer products (such as books, paper or packaging) can be assumed to have a negligible residence time in urban environments (Hashimoto et al. 2004). The latter set, however, have the potential to contribute to the landfill waste sink. In order to quantify annual sequestration of carbon in cities due to forestry products accurately, related material flows must be well understood.

For an urban area (with negligible wood product harvest within its boundaries), the most important consideration for its HWP carbon sink would be the usage phase. A full accounting of year-over-year carbon fluxes would take into consideration upstream emissions (e.g. harvesting, processing and wood wastes emissions) and downstream emissions (from past disposal of wood products). Both of these are neglected in embodied carbon sink inventories.

As sawn wood is the one of the most significant HWP stocks in the urban environment, it is assessed here as an example. Sahely et al (2003) provide an estimate of the total residential lumber added to the building stock in the City of Toronto for the year 1999 (186,000 tons; $31 \mathrm{~m}^{3} /$ house, $450 \mathrm{~kg} / \mathrm{m}^{3}$, based on the construction of 12,855 houses). Using Statistics Canada data from 2006 Census, a similar calculation can be made for 2005 , assuming a constant rate of construction, and including all construction of single detached, semi-detached, row houses, and duplexes. This provides a figure of 14,600 homes, or 204,000 tons of sawnwood. The sawnwood carbon fraction values (IPCC 2003 Good Practices Guideline Tier 2 methodology) presented by Cláudia Dias et al (2009) is used to provide the figure for this embodied sink, simplified using Equation 12.

$$
\text { Carbon Storage (tons } \mathrm{yr}^{-1} \text { ) }=T \bullet C F \bullet D W
$$

where $\mathrm{T}=$ tonnage of wood consumed (tons $\mathrm{yr}^{-1}$ ), $\mathrm{CF}=$ Carbon Fraction per unit of dry weight ( 0.5 for sawnwood), DW $=$ Dry weight conversion factor (average of 0.435 for coniferous sawnwood).

\section{Results}

The current carbon sinks for the GTA are small relative to the carbon sources, but there is potential to increase these sinks. A summary of the GTA carbon sinks quantified for 2005 is found in Table 6, based on one year of direct sink sequestration and one year's consumption for embodied sinks sequestration. Biomass in regional forests provided the greatest sequestration for direct sinks, meanwhile landfills were the largest embodied carbon stock created over a single year. As well, maximum and minimum sequestration values are also provided (see "Uncertainty" for further explanation). Kennedy et al (2010) estimate that the GTA's 2005 scope 1 and 2 (direct emissions and upstream electricity) GHG emissions were approximately $15.8 \mathrm{Mt} \mathrm{C}\left(58 \mathrm{Mt} \mathrm{CO}_{2} \mathrm{e}\right)$. The estimated sequestration in direct sinks in the same year is $0.32 \mathrm{Mt} \mathrm{C}\left(1.2 \mathrm{Mt} \mathrm{CO}_{2} \mathrm{e}\right)$, or $2 \%$ of emissions.

Table 6: Summary of 2005 Direct and Embodied Carbon Sinks in the GTA

\begin{tabular}{llllll} 
Carbon & Estimation & Land & Default & Minimum & Maximum \\
\hline
\end{tabular}




\begin{tabular}{|c|c|c|c|c|c|}
\hline Sink & Method & $\begin{array}{c}\text { Area } \\
\text { (ha) }\end{array}$ & $\begin{array}{c}\text { Annual } \\
\text { Sequestration } \\
\left(\text { tons } \mathbf{C ~} \mathbf{y r}^{-1}\right)\end{array}$ & $\begin{array}{c}\text { Annual } \\
\text { Sequestration } \\
\left(\text { tons }{\left.\mathrm{C} \mathrm{yr}^{-1}\right)}^{-1}\right.\end{array}$ & $\begin{array}{c}\text { Annual } \\
\text { Sequestration } \\
\left(\text { tons } \mathrm{C} \mathrm{yr}^{-1}\right)\end{array}$ \\
\hline $\begin{array}{l}\text { Urban } \\
\text { Forests }\end{array}$ & $\begin{array}{c}\text { IPCC } 2006- \\
\text { Vol 4, } \\
\text { Section } \\
\text { 8.2.1, Tier } 2\end{array}$ & 40,000 & 116,000 & 58,000 & 175,000 \\
\hline $\begin{array}{l}\text { Regional } \\
\text { Forests }\end{array}$ & $\begin{array}{c}\text { IPCC } 2006- \\
\text { Vol 4, } \\
\text { Section } \\
\text { 4.2.1, Tier } 1\end{array}$ & 65,000 & 158,000 & 17,000 & 257,000 \\
\hline $\begin{array}{l}\text { Perennial } \\
\text { Crops }\end{array}$ & $\begin{array}{c}\text { IPCC } 2006- \\
\text { Vol 4, } \\
\text { Section } \\
\text { 5.2.1, Tier } 1\end{array}$ & 5,025 & 11,000 & 3,000 & 18,000 \\
\hline $\begin{array}{c}\text { Agricultural } \\
\text { Soil }\end{array}$ & $\begin{array}{c}\text { IPCC } 2006- \\
\text { Vol } 4, \\
\text { Section } \\
\text { 5.2.3, Tier } 1\end{array}$ & 141,000 & 32,000 & 0 & 90,000 \\
\hline Landfills & $\begin{array}{c}\text { USEPA, } \\
2006\end{array}$ & $\mathrm{~N} / \mathrm{A}$ & 131,000 & $(859,000)^{1}$ & $\mathrm{NC}$ \\
\hline Concrete & $\begin{array}{c}\text { Pade and } \\
\text { Guimaraes, } \\
2007\end{array}$ & $\mathrm{~N} / \mathrm{A}$ & 59,000 & $44,000^{2}$ & $73,000^{2}$ \\
\hline HWP & $\begin{array}{c}\text { Modified } \\
\text { from IPCC } \\
2003 \text { Good } \\
\text { Practices } \\
\text { Guideline, } \\
\text { Tier } 2\end{array}$ & $\mathrm{~N} / \mathrm{A}$ & 44,000 & 43,000 & 46,000 \\
\hline
\end{tabular}

$\mathrm{NC}=$ not calculated; 1 - This suggests an emission, with the assumption that no landfill gas is captured; 2 Maximum and minimum Nordic Values

Assuming landfill waste is not disturbed, waste from the GTA deposited in landfills in 2005 will provide a carbon sink of $131,000 \mathrm{tC}$. The resultant anticipated $\mathrm{C}$ uptake for concrete laid in 2005 is 59,000 tC. HWP calculations examined sawnwood exclusively, being the largest fraction of global durable HWP consumption (FAO, 2005), giving a sink of roughly 44,000 tons $\mathrm{C}$ in 2005 for the GTA. This provides some insight as to the scale of the sink HWPs provide, though further consideration of book/paper and wood-based panel stock changes would provide a wider, more complete expansion of scope.

In quantifying embodied sinks from HWPs and waste, it is important to note that a danger of double-counting exists. HWPs often end up in the waste stream and if their disposal occurs within the same year as they are imported to an urban area, the sink can be counted twice. Hence, HWP sinks should be based on wood imported in a year minus the fraction that ends up as construction waste. This was not included in the calculation above as data on HWPs from demolition and other uses (commercial building construction, apartments, industrial applications) are incomplete. 


\section{Uncertainty}

There is uncertainty associated with all methodologies attempting to quantify sources and sinks and those used with embodied sinks that should be highlighted. Given that IPCC guidelines used here (Tier 1 and 2) applied mean values from a region or climate zone, error values associated with these means can be employed to determine the range of possible carbon storage potential for the sinks identified. Table 6 provides these ranges based on those stated in the IPCC 2006 guidelines.

With regards to the urban forests, measured data is available for the City of Toronto through a UFORE study, with limited date available for the other municipalities within the GTA. The data from the UFORE study suggests the figure calculated based on the City of Toronto's urban canopy from the IPCC 2006 guidelines is a good approximation of that obtained with detailed tree surveys and field measurements $(28,000$ tons $\mathrm{C}$ from UFORE vs 31,000 tons $\mathrm{C}$ from the IPCC methodology).

Carbon sequestered in embodied sinks could have greater uncertainty than direct sinks, as these are projections based on future sink management. The permanence of these sinks is, however, uncertain. Landfills, as an example, could be mined in the future, which would subject waste to aerobic conditions. Depending on the duration of exposure to these conditions or the end use of mined materials (i.e. combustion), significant emissions of carbon (presumed to be stored indefinitely) can occur.

HWP storage in structures is expected to have long-term stability (maintained in the built environment for nearly a century). If, by century's end, present emissions reductions targets are realized, the release from HWP decay will be within the context of a low carbon urban system. However, disturbances (such as fire or decay), retrofits, and demolition could shorten the actual carbon release horizon. Additionally, uncertainty in the actual emissions and climate change scenarios at the time of release may result in HWP exacerbating future challenges.

Finally, concrete carbonization projections are based on Nordic averages of cement usage. The amount of carbonization in the 100-year is dependent on the end use of cement, which dictate key absorption factors such as thickness of structural elements and exposure conditions (Pade and Guimaraes, 2007). Actual carbonization rate may vary based on factors such as floor area density (i.e. proportion of concrete exposed to indoor conditions), concrete formulation (use of supplementary cementitious materials) or climate (relative humidity). Additionally, a large proportion of carbonization suggested by the Pade and Guimaraes (2007) comes from the creation of rubble of demolished concrete structures for use as an aggregate replacement. Proportion of concrete recycled will be dependent local practices.

\section{Discussion - Potential for Carbon Sink Enhancement}

Options exist to create or expand carbon sinks associated with urban regions. Many of these are commercially feasible at present, though others are speculative, with research ongoing. The sinks discussed below are described within the GTA context, yet their relevance is broader, as there is the potential for several of these to be applied elsewhere. 
Opportunities to sequester carbon are not limited to those quantified above, and many of the sinks described in this section are also applicable to other urban centres. A variety of large point source industrial emitters exist within the GTA, even though the region is undergoing a transition from an industrial-based to a service-based economy. In 2005, over 14.5 Mt of $\mathrm{CO}_{2} \mathrm{e}$ were released from facilities emitting $100 \mathrm{kt}$ of $\mathrm{CO}_{2} \mathrm{e}$ per annum in the GTA (Environment Canada, 2009). It is likely that cost-effectiveness of projects intended to utilize waste $\mathrm{CO}_{2}$ streams will increase for larger point-source emitters (rather than smaller emissions sources, such as private residences); as a result, it may be possible to create further carbon sinks within the urban environment that utilize these flue gases.

With the potential for the installation of district energy systems within the GTA, it is possible to utilize low grade heat and $\mathrm{CO}_{2}$ from flue gases. Some uses for $\mathrm{CO}_{2}$ that have received attention recently include algae fertilization as a feedstock for biofuels and soil fertilization (Packer, 2009). Additionally, $\mathrm{CO}_{2}$ has the potential for use as an industrial feedstock, including polymers or synthetic fuels, though significant economic barriers exist to wider use of these applications (Aresta and Dibenedetto, 2007).

Another potential use for $\mathrm{CO}_{2}$ is to increase its concentration in greenhouse environments. Studies have shown that crops grown at elevated temperatures, with greater nutrient availability and at a higher $\mathrm{CO}_{2}$ concentrations (between 600-900 ppm is generally the optimal concentration) have an increased yield and decreased time to flowering (Ontario Ministry of Agriculture and Rural Affairs, 2005; Mortensen, 1987). Huang and $\mathrm{Bi}$ (2006) propose that by integrating biogas production from agricultural wastes with greenhouse operations, the offset of natural gas combustion would amount to 3200 tons $\mathrm{CO}_{2} \mathrm{e} \mathrm{ha}^{-1} \mathrm{yr}^{-1}$. Depending on how wastes from yields are disposed of through the supply chain (i.e. landfill, composted/digested into soil conditioner), carbon stocks could potentially increase as a result.

Point-source emitters also present an opportunity for carbon separation and storage (or carbon capture and storage, CCS), however this option is still in the development phase. CCS opportunities in southern Ontario are available in saline aquifers whose capacities are estimated at more than $700 \mathrm{Mt} \mathrm{CO}_{2}$, though the injection point would be roughly 250 $\mathrm{km}$ from the GTA (Shafeen et al, 2004a). Shafeen et al (2004b) also estimate that the sequestration infrastructure costs for $5 \mathrm{Mt} \mathrm{CO}_{2} \mathrm{yr}^{-1}$ would be between 27 and $50 \mathrm{USD} / \mathrm{tC}$, however the cost of separation is likely to cause this to increase to $275 \mathrm{USD} / \mathrm{tC}$.

Additionally, McKinsey \& Company (2009) have suggested that CCS is on the high end of the spectrum of GHG mitigation solutions. Singh et al. (2011) also suggest that emissions from CCS other than GHGs are considerable. CCS is also being explored through capture of ambient $\mathrm{CO}_{2}$ by means of chemical scrubbing technologies that could be applied at remote sites, eliminating costs for transportation (Lackner and Brennan. 2009; Keith. 2009). These ambient air $\mathrm{CO}_{2}$ removal technologies would not likely be applied within a dense urban environment, though may fall within a city's domain of influence.

A number of additional carbon storage options which use biomass feedstocks, hence removing atmospheric carbon, have been described in literature. Some examples include biochar production (Dover, 2007) with soil application and biomass electricity generation with CCS (Möllerston et al, 2003). There is potential for these options to provide carbon sinks in instances where emissions from biogenic sources would have resulted (such as in 
regions where biomass is being affected by severe pest disturbances). However, these options are likely beyond the sphere of municipal governmental influence (agriculture and electricity). Additionally, increased use of HWPs could enhance this sink, with a provincial-level example in British Columbia, where the building code was recently altered to increase the maximum height of wood-frame construction from four to six storeys (Province of British Columbia, 2009). This limit on wood-frame building height may be conservative; plans exist for the construction of a 30-storey wooden building in Austria (Inhabitat, 2010).

Green roofs represent another potential future carbon sink within the GTA, as they can be classified as grasslands (i.e. areas used for livestock grazing that would not regrow as forest under natural conditions). Green roofs have indirect emissions reduction benefits, such as reducing cooling and heating loads through evaporative cooling and increased thermal insulation, respectively (Saiz et al, 2006). No studies have been conducted on the potential area for extensive green roof installations for the wider GTA, though Banting et al (2005) have conducted an analysis based on GIS data for the City of Toronto.

Banting et al (2005) assessed potential greenroof capacity in the City of Toronto on all flat roofs greater than $350 \mathrm{~m}^{2}$, with $75 \%$ roof coverage and estimate 5,000 ha of compatible roof area exist. Using carbon storage values in above/below ground biomass and substrate carbon provided by Getter et al (2009; total of $\left.375 \mathrm{~g} \mathrm{C} \mathrm{m}^{-2} \mathrm{yr}^{-1}\right)$, approximate values for extensive greenroofs carbon sequestration potential for the City of

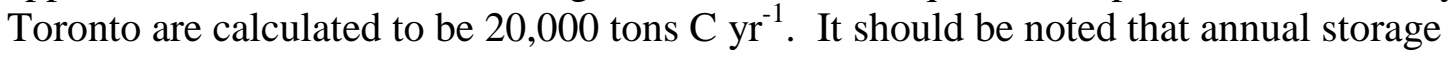
potential has an underlying assumption of continued biomass growth and unsaturated substrate conditions, which will be dependant on greenroof and waste management activities.

\section{Comparison with the Producer/Consumer Emissions Concept}

The distinction between consumer and producer GHG emissions has received attention in recent years due to perceived inequity in allocation in current inventorying practices (Davis and Caldeira, 2010; Peters, 2008; Weber et al. 2007, 2008); essentially, when taking a producer approach to emissions inventorying, few upstream emissions are attributed to the consumer of goods and services. This leads to an "outsourcing" of GHG emissions as developed nations transition away from manufacturing economies and rely on developing countries for an increasing proportion of goods and services. The degree of exclusion of these emissions is exacerbated on the urban scale by narrowing the spatial boundaries further. Consumer-based methodologies allow for the accounting of upstream emissions occurring beyond the jurisdictional boundary of the final consumer, with many urban examples currently being employed (Kennedy et al. 2010; Hillman 2010; Ramaswami et al. 2008; Lenzen and Peters. 2010; Minx et al. 2009; Schulz. 2010).

It is of interest to compare the direct versus embodied carbon sink concept to producer/consumer emissions responsibility allocation literature, as allocation is relevant to both. In this article, the issue of allocation for sinks is simplified; both direct and embodied sinks are allocated within the spatial boundary of the inventory to the benefit of that jurisdiction. 
Conventional emission quantification approaches have generally been producerallocation, relieving consumers of their due share of responsibility. Consumer emissions allocation (perhaps equally unfairly) shifts all responsibility to the end-user. In a sense, embodied sinks do the opposite; embodied sinks shift all of the responsibility of emissions to the producer, whereas the consumer reaps the benefit of a negative figure on their carbon balance sheet from the creation of a carbon stock. There is the potential to use a more sophisticated allocation method for embodied sinks in theory, such as the value-added method suggested by Lenzen et al (2007). However, the challenges in identifying components of the supply chain, especially when examining a sink as complex as landfilled waste, puts this approach beyond the scope of this article.

\section{Conclusion}

Embodied and direct sinks require differentiation as they tell different stories of carbon storage. Direct sinks store carbon due to land use management activities within an urban region, promoting the production of a biogenic carbon stock. An embodied sink may or may not occur within inventorying boundary, but a carbon stock is created through consumption activities occurring inside the urban region's jurisdictional limits.

Gross carbon sink quantification for the GTA shows direct sinks assessed are greater than the embodied sinks assessed, though inclusion of upstream and downstream emissions will likely convert the latter to net GHG sources. The magnitude of direct sinks may also be reduced when considering a broader scope of activities associated with their management.

Pouyat et al (2009) argue for the concept of "Urban Ecosystem Convergence", where urban systems transition towards providing the same ecological services as would be provided under natural conditions. The different options presented above provide engineered solutions to attaining and potentially surpassing what would ordinarily be possible from a carbon sequestration standpoint. Some policy initiatives that would increase the capacity of existing urban carbon sinks are:

1) Conversion of marginal agricultural land to grassland or forestland

2) Halt development on agricultural, wetlands and forest land

3) Promote the planting of street trees and other urban greenery (including low maintenance urban forests, greenroofs and urban agriculture with waste heat and $\mathrm{CO}_{2}$ utilization)

4) Encouragement of conservation agriculture, such as tillage reduction (where appropriate)

5) Promotion of wood-framed construction over concrete, where possible

It is important to note that the intention of this work was not to quantify sinks for the purpose of carbon credit allocation, rather to assess their magnitude, differentiate between direct and embodied sinks and gain greater insight into the discrepancy between GHG sources and sinks. A long-term target for sustainable cities should be to address this disparity and close the carbon loop.

\section{$\underline{\text { Acknowledgements }}$}


The authors would like to thank the anonymous reviewers of this article, as well as

Danny Harvey, for their comments. As well, we greatly appreciate the assistance of Rike Burkhardt (City of Toronto), Dan Clayton (TRCA), Meaghan Eastwood (TRCA), Andy Kenney (University of Toronto), John McNeil (City of Oakville), and Andrew Pickett (City of Toronto). 


\section{References:}

Akbari, H. 2002. Shade trees reduce building energy use and $\mathrm{CO} 2$ emissions from power plants. Environmental Pollution 116(SUPPL. 1): S119-S126.

Aresta, M. and Dibenedetto, A. 2007, "Utilisation of $\mathrm{CO}_{2}$ as a chemical feedstock: Opportunities and challenges", Dalton Transactions, , no. 28, pp. 2975-2992.

Banting D., Doshi, H., Li, J., Missos, P., Au, A., Currie, B.A., and Verrati, M. 2005. Report on the Environnemental Benefits and Costs of Green Roof Technology for the City of Toronto. [Online] Available HTTP: http://www.toronto.ca/greenroofs/pdf/fullreport103105.pdf. Accessed December 22, 2010.

Barlaz, M.A. 1998, "Carbon storage during biodegradation of municipal solid waste components in laboratory-scale landfills", Global Biogeochemical Cycles, vol. 12, no. 2, pp. 373-380.

Barlaz, M.A. 2008, “Corrections to Published Carbon Storage Factors for Mixed Municipal Waste" [Online] Available HTTP: http://epa.gov/climatechange/wycd/waste/downloads/Sequestration_Correction2_102 708.pdf, Accessed September 30, 2010.

Christmas Tree Farmers of Ontario, 2010. Real Tree Facts. [Online] Available HTTP: http://www.christmastrees.on.ca/consumers/real-tree-facts.html. Accessed October 26,2010

City of Toronto, 1991. SWEAP - Solid Waste Environmental Assessment Plan. Component 4: Solid Waste Management System Inventory - Waste Composition Study. Solid Waste Management Division, Metropolitan Toronto Department of Works.

Cláudia Dias, A., Louro, M., Arroja, L. \& Capela, I. 2009, "Comparison of methods for estimating carbon in harvested wood products", Biomass and Bioenergy, vol. 33, no. 2, pp. 213-222.

Davis, S.J. and Caldeira, K. 2010, "Consumption-based accounting of $\mathrm{CO}_{2}$ emissions", Proceedings of the National Academy of Sciences, vol. 107, no. 12, pp. 5687-5692.

Dover, M. 2007, "Anyone for char? Dark earth holds carbon storage hope", Inwood, , no. 77, pp. 33.

Environment Canada, 2009. Greenhouse Gas Reporting. [Online] Available HTTP: http://www.ghgreporting.gc.ca/default.asp?lang=En\&n=FA37B3F0-1, Accessed December 20, 2009.

Food and Agriculture Organization, 2005. Trends in Wood Products, 1961-2003. ISBN 92-5-005377-0.

Galan, I., C. Andrade, P. Mora, and M. A. Sanjuan. 2010. Sequestration of CO2 by concrete carbonation. Environmental Science and Technology 44(8): 3181-3186.

Getter, K.L., Rowe, D.B., Robertson, G.P., Cregg, B.M. and Andresen, J.A. 2009, "Carbon Sequestration Potential of Extensive Green Roofs", Environmental science \& technology, .

Haselbach, L.M. and Ma, S. 2008, "Potential for carbon adsorption on concrete: Surface XPS analyses", Environmental Science and Technology, vol. 42, no. 14, pp. 53295334.

Hashimoto, S., M. Nose, T. Obara, and Y. Moriguchi. 2002. Wood products: Potential carbon sequestration and impact on net carbon emissions of industrialized countries. Environmental Science and Policy 5(2): 183-193. 
Hashimoto, S., Y. Moriguchi, A. Saito, and T. Ono. 2004. Six indicators of material cycles for describing society's metabolism: Application to wood resources in Japan. Resources, Conservation and Recycling 40(3): 201-223.

Hillman, T. 2010, "Greenhouse gas emission footprints and energy use benchmarks for eight U.S. cities", Environmental science technology, vol. 44, no. 6, pp. 1902.

Huang, Z.Y. and Bi, H.T. 2006, Regional Energy Integration to Reduce GHG Emissions and Improve Local Air Quality.

IPCC, 2000. Land Use, Land-use Change and Forestry [Robert T. Watson, Ian R. Noble, Bert Bolin, N. H. Ravindranath, David J. Verardo and David J. Dokken (Eds.)] Cambridge University Press, UK. 375 pp.

IPCC, 2006. Guidelines for National Greenhouse Gas Inventories. [Simon Eggelston, Leandro Buendia, Kyoko Miwa, Todd Ngara, Kiyoto Tanabe (Eds.)] Published by the Institute for Global Environmental Strategies (IGES) for the IPCC. ISBN 488788-032-4

IPCC, 2007. Climate Change 2007: The Physical Science Basis. Contribution of Working Group I to the Fourth Assessment Report of the Intergovernmental Panel on Climate Change [Solomon, S., D. Qin, M. Manning, Z. Chen, M. Marquis, K.B. Avery, M. Tignor and H.L. Miller (eds.)]. Cambridge University Press, Cambridge, United Kingdom and New York, NY, USA, 996 pp.

Inhabitat, 2010. Lifecycle Building in Austria Will Be World's Tallest Wooden Building. [Online] Available HTTP: http://inhabitat.com/lifecycle-tower-in-austriawill-be-worlds-tallest-wooden-building/ Accessed April 19, 2011.

International Fund for Agricultural Development, 2000. Carbon Sequestration Options Under the Clean Development Mechanism to Address Land Degradation. World Soil Resources Reports, 92, ISSN 0532-0488

Keith, D. W. 2009. Why capture CO2 from the atmosphere? Science 325(5948): 16541655.

Kennedy C.A., Ramaswami A., Carney S., and Dhakal S., 2009. Greenhouse Gas Emission Baselines for Global Cities and Metropolitan Regions. [Online] Available HTTP:

http://siteresources.worldbank.org/INTURBANDEVELOPMENT/Resources/33638 7-1256566800920/6505269-1268260567624/KennedyComm.pdf, November 15, 2010

Kennedy, C., Steinberger, J., Gasson, B., Hansen, Y., Hillman, T., Havránek, M., Pataki, D., Phdungsilp, A., Ramaswami, A. and Mendez, G.V. 2010, "Methodology for inventorying greenhouse gas emissions from global cities", Energy Policy, vol. 38, no. 9, pp. 4828-4837.

Kenney, W.A., C. Idziak, and C. Anderson. 2001. The role of urban forests in greenhouse gas reduction. Report submitted to the Ontario Ministry of Environment. Contract ON ENV (99) 4691. $220 \mathrm{p}$

Kirschbaum, M.U.F. 2000, "Will changes in soil organic carbon act as a positive or negative feedback on global warming?", Biogeochemistry, vol. 48, no. 1, pp. 21-51.

Lackner, K. S. and S. Brennan. 2009. Envisioning carbon capture and storage: Expanded possibilities due to air capture, leakage insurance, and C-14 monitoring. Climatic Change 96(3: 357-378.

Lenzen, M., J. Murray, F. Sack, and T. Wiedmann. 2007. Shared producer and consumer responsibility - Theory and practice. Ecological Economics 61(1): 27-42.

Lenzen, M. and G. M. Peters. 2010. How City dwellers affect their resource Hinterland. Journal of Industrial Ecology 14(1): 73-90. 
Luyssaert, S., Schulze, E.-., Börner, A., Knohl, A., Hessenmöller, D., Law, B.E., Ciais, P. and Grace, J. 2008, "Old-growth forests as global carbon sinks", Nature, vol. 455, no.

7210, pp. 213-215.

McKinsey \& Co., 2009. Pathways to a Low-Carbon Economy: Version 2 of the Global Greenhouse Gas Abatement Cost Curve. [Online] Available HTTP: http://www.mckinsey.com/clientservice/sustainability/pathways_low_carbon_econo my.asp, Accessed, November 19, 2010.

McPherson, E.G. 1998, "Atmospheric carbon dioxide reduction by Sacramento's urban forest", Journal of Arboriculture, vol. 24, no. 4, pp. 215-223.

Miner, R. and Perez-Garcia, J. 2007, "The carbon and greenhouse gas profile of the global forest products industry", Forest Product Journal, 57 (10), 80-90.

Minx, J. C., T. Wiedmann, R. Wood, G. P. Peters, M. Lenzen, A. Owen, K. Scott, J. Barrett, K. Hubacek, G. Baiocchi, A. Paul, E. Dawkins, J. Briggs, D. Guan, S. Suh, and F. Ackerman. 2009. Input-output analysis and carbon footprinting: An overview of applications. Economic Systems Research 21(3): 187-216.

Mohareb, E., MacLean, H.L., and Kennedy, C.A., 2011. Greenhouse Gas Emissions from Waste Management - Assessment of Quantification Methods. Journal of the Air and Waste Management Association. 61, pp. 480-493.

Möllersten K., Yan J., and Moreira J.R., 2003. Potential market niches for biomass energy with $\mathrm{CO}_{2}$ capture and storage-Opportunities for energy supply with negative $\mathrm{CO}_{2}$ emissions. Biomass and Bioenergy, 25 (3), pp. 273-285.

Mortensen, L.M. 1987, "Review: CO2 enrichment in greenhouses. Crop responses", Scientia Horticulturae, vol. 33, no. 1-2, pp. 1-25.

Munksgaard, J. and Pedersen, K.A. 2001, "CO2 accounts for open economies: producer or consumer responsibility?", Energy Policy, vol. 29, no. 4, pp. 327-334.

Novomer, 2008. Novomer - Catalyzing Green Chemistry. [Online] Available HTTP: http://www.novomer.com/, Accessed January 19, 2010.

Nowak, D.J. and Crane, D.E. 2002, "Carbon storage and sequestration by urban trees in the USA", Environmental Pollution, vol. 116, no. 3, pp. 381-389.

Ontario Ministry of Agriculture and Rural Affairs, 2005. Growing Greenhouse Vegetables - Publication 371. Queen's Printer, Toronto, ON.

Packer, M. 2009, "Algal capture of carbon dioxide; biomass generation as a tool for greenhouse gas mitigation with reference to New Zealand energy strategy and policy", Energy Policy, vol. 37, no. 9, pp. 3428-3437.

Pade, C. and Guimaraes, M. 2007, "The CO2 uptake of concrete in a 100 year perspective", Cement and Concrete Research, vol. 37, no. 9, pp. 1348-1356.

Pataki, D.E., Alig, R.J., Fung, A.S., Golubiewski, N.E., Kennedy, C.A., Mcpherson, E.G., Nowak, D.J., Pouyat, R.V. and Lankao, P.R. 2006, "Urban ecosystems and the North American carbon cycle", Global Change Biology, vol. 12, no. 11, pp. 2092-2102.

Peters, G.P. 2008, "From production-based to consumption-based national emission inventories", Ecological Economics, vol. 65, no. 1, pp. 13-23.

Post, W.M. and Kwon, K.C. 2000, "Soil carbon sequestration and land-use change: Processes and potential", Global Change Biology, vol. 6, no. 3, pp. 317-327.

Pouyat, R. 2002, "Soil carbon pools and fluxes in urban ecosystems", Environmental pollution, vol. 116, no. SUPPL. 1, pp. S107.

Pouyat, R.V., Yesilonis, I.D. and Nowak, D.J. 2006, "Carbon storage by urban soils in the United States", Journal of environmental quality, vol. 35, no. 4, pp. 1566-1575. 
Pouyat, R.V., Yesilonis, I.D. and Golubiewski, N.E. 2009, "A comparison of soil organic carbon stocks between residential turf grass and native soil", Urban Ecosystems, vol. 12 , no. 1 , pp. 45-62.

Province of British Columbia, 2009. Residential Mid-Rise Wood-Frame Code Change. [Online] Available HTTP: http://www.housing.gov.bc.ca/building/wood_frame/, (Accessed August 5, 2009)

Ramaswami, A., Hillman, T., Janson, B., Reiner, M. and Thomas, G. 2008, "A DemandCentered, Hybrid Life-Cycle Methodology for City-Scale Greenhouse Gas Inventories", Environmental Science \& Technology, vol. 42, no. 17, pp. 6455-6461.

Rees, W.E. 1997, "Is 'sustainable city' an oxymoron?", Local Environment, vol. 2, no. 3, pp. 303-310.

Robert, M. 2001, Soil carbon sequestration for improved land management, Food and Agricultural Organization of the United Nations, Rome.

Sahely, H.R., Dudding, S. and Kennedy, C.A. 2003a, "Estimating the urban metabolism of Canadian cities: Greater Toronto Area case study", Canadian Journal of Civil Engineering, vol. 30, no. 2, pp. 468-483.

Saiz, S., Kennedy, C., Bass, B. and Pressnail, K. 2006, "Comparative life cycle assessment of standard and green roofs", Environmental Science and Technology, vol. 40, no. 13, pp. 4312-4316.

Satterthwaite, D. 2008, "Cities' contribution to global warming: Notes on the allocation of greenhouse gas emissions", Environment and Urbanization, vol. 20, no. 2, pp. 539549.

Schulz, N. B. 2010. Delving into the carbon footprints of Singapore - comparing direct and indirect greenhouse gas emissions of a small and open economic system. Energy Policy 38(9): 4848-55.

Shafeen, A., Croiset, E., Douglas, P.L. and Chatzis, I. 2004a, "CO2 sequestration in Ontario, Canada. Part I: Storage evaluation of potential reservoirs", Energy Conversion and Management, vol. 45, no. 17, pp. 2645-2659.

Shafeen, A., Croiset, E., Douglas, P.L. and Chatzis, I. 2004b, "CO2 sequestration in Ontario, Canada. Part II: Cost estimation", Energy Conversion and Management, vol. 45, no. 20, pp. 3207-3217.

Singh, B., A. H. Strømman, and E. Hertwich. 2011. Life cycle assessment of natural gas combined cycle power plant with post-combustion carbon capture, transport and storage. International Journal of Greenhouse Gas Control 5(3: 457-466.

Statistics Canada, 2002. Census of Agriculture, 2001.

Statistics Canada, 2007. Census of Agriculture, 2006 - Community Profiles.

Statistics Canada, 2008. Census of Agriculture, 2006 - Summary Tables.

Statistics Canada, 2010. CMHC, housing starts, under construction and completions in centres 10,000 and over, Canada, provinces, selected census metropolitan areas, monthly (Units). Table 270001.

Stewardship Ontario, 2006. Stewardship Ontario’s E \& E Fund - Waste Audit Program. [Online] Available HTTP: http://www.stewardshipontario.ca/bluebox/eefund/projects/audits/waste_audit.htm, Accessed January 6, 2010.

Toronto City Summit Alliance, 2008. Greening Greater Toronto. [Online] Available HTTP: http://www.greeninggreatertoronto.ca/pdf/June2008Report.pdf Accessed December 22, 2010. 
Town of Oakville, 2006. Oakville's Urban Forest: Our Solution to Our Pollution.

[Online] Available HTTP: http://www.oakville.ca/Media_Files/forestry/UFORE.pdf (Accessed August 31, 2009)

USDA, 2010. Urban Forest Effects Model (UFORE) - UFORE in Action, Toronto, ON. [Online] Available HTTP: http://www.ufore.org/action/09-00.html (Accessed November 1, 2010)

United Nations, 2008. World Urbanization Prospects. The 2007 Revision - Executive Summary. New York: United Nations, Department of Economic and Social Affairs, Population Division. [Online]. Available HTTP:

http://www.un.org/esa/population/publications/wup2007/2007WUP_ExecSum_web .pdf (Accessed July 23, 2009)

United States Environmental Protection Agency, 2006. Solid Waste Management and Greenhouse Gases - A Life-Cycle Assessment of Emissions and Sinks, $3^{\text {rd }} \mathrm{Ed}$. [Online] Available HTTP: http://epa.gov/climatechange/wycd/waste/SWMGHGreport.html.

United States Environmental Protection Agency, 2009. Inventory of U.S. Greenhouse Gas Emissions and Sinks - 1990-2007. EPA 430-R-09-004.

VandenBygaart, A.J., Gregorich, E.G., Angers, D.A. and Stoklas, U.F. 2004, "Uncertainty analysis of soil organic carbon stock change in Canadian cropland from 1991 to 2001", Global Change Biology, vol. 10, no. 6, pp. 983-994.

Weber, C.L., Matthews, H.S., Corbett, J.J. and Williams, E.D. 2007, "Carbon emissions embodied in importation, transport and retail of electronics in the U.S.: A growing global issue", , pp. 174.

Weber, C.L., Peters, G.P., Guan, D. and Hubacek, K. 2008, "The contribution of Chinese exports to climate change", Energy Policy, vol. 36, no. 9, pp. 3572-3577.

Wright RM, 2000. "The Evolving Physical Condition of the Greater Toronto Area: Space, Form and Change". Report to the Neptis Foundation. Toronto: University of Toronto. 


\section{Supplemental Materials - Unquantified Sources and Sinks}

For each type of sink identified, a number of emissions sources can be identified which have not been quantified that have the potential to greatly diminish the net carbon sinks (Table 3.7). As the objective was purely gross sink quantification to identify the scale of sinks and their potential expansion, emissions were not quantified. It is important to note then that if sink expansion were to be pursued, consideration must be made in policy decisions to ensure that net emissions are not positive.

Table 0-1: Unquantified Sources Associated with Carbon Sinks Quantified for the

\section{GTA}

\begin{tabular}{ll}
\multicolumn{1}{c}{ Sink } & Associated Emissions \\
\hline Forest & Decaying Dead Organic Matter (Litter, Infestations, Fire, Disease) \\
\hline Agriculture & $\begin{array}{l}\mathrm{N}_{2} \mathrm{O} \text { from Application of Manure / Synthetic Nitrogen Fertilizer, Crop } \\
\text { Residue Decomposition, Cultivation, Summerfallowing \& Irrigation }\end{array}$ \\
\hline $\begin{array}{l}\text { Harvested } \\
\text { Wood } \\
\text { Products }\end{array}$ & Harvesting, Processing, Storage, Transportation, Usage \\
\hline Concrete & Cement Production, Transportation \& Usage \\
\hline Landfills & $\begin{array}{l}\text { Biogenic Carbon Harvesting, Processing, Storage, Usage \& } \\
\text { Transportation, Landfill Operations }\end{array}$ \\
\hline
\end{tabular}

\section{Forestry}

Annual carbon losses can be assessed by tabulating all wood removals (for fuel wood and HWPs) and trees affected by disturbances (IPCC, 2006). Wood removals and fuelwood losses are most significant in regions with commercial logging operations. Assuming that no commercial removal operations (with the exception of Christmas tree plantations and nurseries) are present in the GTA, these losses are assumed to be zero. Discussion of tree removal is found in the perennial crop discussion in Section 3.1.1. It is assumed that other disturbances are negligible in the GTA for the year 2005. Tier 1 methodologies assume that carbon releases from litter are balanced by annual additions, creating a balanced carbon stock. The magnitude of carbon release from litter has been measured to be on the order of 1-2 tC / ha; however, inputs of new litter are generally in the same range and these were also not tabulated (Jonard et al., 2007; Ngao et al., 2005; Sulzman et al., 2005; Edwards \&Harris 1977).

Disturbances, such as fire, pests or disease, can result in further carbon emissions and are an ongoing concern in the GTA. The City of Toronto, as an example, is currently contending with an infestation of Emerald Ash Borer (EAB) and Asian Long-Horned Beetle (ALHB), to which at least $6 \%$ (up to $10 \%$ in surrounding areas; Toronto Star, 2009) and $50 \%$ of public street trees are susceptible to attack, respectively (City of Toronto, 2009). The ALHB infestation resulted in the removal of over 23,000 trees as of 2004. This is less than $1 \%$ of the 3 million trees on public property. Annual statistics on the extent of disturbances will be valuable in the quantification process, especially in relation to DOM. Given the scale of infestation in 2005, these are assumed to be negligible for the GTA. 
Soils

While carbon stocks may be increasing in cropland soils due to conservation agriculture techniques, emissions from these soils are not insignificant. The 2008 Canadian National Inventory Report suggests that agricultural soils provided $18 \mathrm{Mt}$ of $\mathrm{CO}_{2} \mathrm{e}$ due to the sources listed in Table 3.7. Using the 2006 Census figure of roughly 36 million hectares, this represents an average of $0.5 \mathrm{t} \mathrm{CO}_{2} \mathrm{e}$ per ha (Statistics Canada, 2008). Additionally, Rochette et al., (2008) suggest that in heavy clay soils, $\mathrm{N}_{2} \mathrm{O}$ emissions from denitrification caused by organic matter decomposition may exceed the benefits of soil carbon storage.

Gains in carbon stocks in urban areas are difficult to quantify due to uncertainty in management and land cover. Since urban forest area correlate with canopy cover, overlap can occur with turfgrass and forestry area. If one were to make the assumption that all pervious land area in the GTA turfgrass, and one neglects aboveground and belowground inputs from trees, and applies gross rates of storage from literature $\left(0.32-0.78 \mathrm{tC} \mathrm{ha}^{-1} \mathrm{yr}^{-1}\right.$; Qian et al, 2010), it is seen that urban soils have the potential to sequester between 38,000 and 85,000 tC annually (assuming that GTA urban areas are 50\% pervious). However, it should be mentioned that turfgrass maintenance generally has numerous carbon inputs (mowing, fertilization \& irrigation) that result in direct and indirect emissions, reducing the net carbon storage significantly.

Changes in SOC in urban forest soils were also not quantified. Berg et al., (2009) suggest that a mean sequestration in Swedish forest soils of $251 \mathrm{~kg} \mathrm{C} \mathrm{ha}^{-1} \mathrm{yr}^{-1}$, with the potential

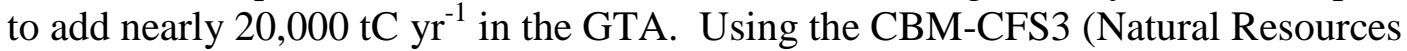
Canada, 2009) forest carbon tool (and assuming the average age of forests in the GTA is 60 years), both DOM and soil carbon could potentially amount to 46,000 tC $\mathrm{yr}^{-1}$.

\section{Harvested Wood Products (HWP)}

Emissions from the harvest \& processing of HWPs may be the closest in balancing with the resultant sink when compared with the other embodied sinks quantified; however, this is uncertain based on the forest stand management, harvesting, processing methods \& end use. White et al., (2005) studied roundwood production in Wisconsin, and suggest that the net forest carbon budget, taking a full life cycle approach, ranges from -897 to $348 \mathrm{~g}$ $\mathrm{C} \mathrm{m}^{-2} \mathrm{yr}^{-1}$, i.e. it can be a net source or a net sink prior to use. Côté et al., (2002) found that by the time HWPs are ready for delivery to the consumer, 1.8 times the amount of carbon emissions are released as are stored in the end product. However, net carbon storage was positive when including carbon stocks retained in the harvest forest and in landfill sites for ultimate disposal., This suggests that the full HWP cycle from forest management to disposal can be a system for carbon storage.

\section{Concrete}

Absorption of carbon during concrete carbonation can indeed result in carbon storage. If one were only to consider the carbon balance associated with concrete stocks for a city which did not manufacture cement, the carbon sequestered may be surprisingly large. However, if upstream carbon emissions from cement production (calcination and fossil fuel combustion, each contributing 50\% of production-related emissions) are included, net emissions would be around $200 \mathrm{ktC}$ using the estimation method of Pade \& Guimaraes (2007). Even this provides a conservative figure, as it neglects emissions associated with transportation, pouring and demolition. One further point of interest is that two cement plant exists within the regional boundaries of the GTA (though the destination of this cement is uncertain), emitting roughly $380 \mathrm{ktC}$ in 2005 (Environment Canada, 2008). 


\section{Landfills}

Landfills have represented the largest MSW treatment option in the US and Canada

historically and do provide storage capacity of carbon, but justifying this option as a sole alternative for waste disposal based on GHG-reduction benefits would be disingenuous. Significant emissions occur upstream from the manufacture of the products containing biogenic carbon that provide the waste sink. This emphasizes the need for considering additional factors other than carbon storage alone when deciding on waste treatment options (such as life cycle energy consumption or forestry resource preservation). For the sake of comparison, USEPA (2006) coefficients suggest that recycling of the same materials that provide this sink (biogenic carbon, not including food waste) would reduce upstream emissions by up to $2,000,000 \mathrm{tC}$ (in place of using virgin materials). 